\title{
Loss of Diversification of fish species in Meerut region: A Threat to natural fauna
}

\author{
Shobhna ${ }^{1}$, Manu varma ${ }^{2}$, Seema Jain ${ }^{2} \&$ Hridaya Shanker Singh ${ }^{1}$ \\ ${ }^{I}$ (Department of Zoology, Ch. Charan Singh University, Meerut - 250004, India) \\ ${ }_{2}^{2}$ (Department of Zoology, R. G.P.G.College, Meerut - 250004, India)
}

\begin{abstract}
The freshwater aquatic biodiversity is depleting alarmingly due to introduction of exotic species, diseases, habitat loss, pollution, overexploitation and other anthropogenic activities. Loss of biodiversity is severe in freshwater ecosystem which represents a meager of 0.1 percent of earth's water wealth, yet they harbor 40 percent of the fish species so far recorded. Nearly 20 percent of the world's freshwater fish fauna is already extinct or is on the urge of extinction. The potential risks not only affect the biodiversity but also the socioeconomic aspects of the human community that depend on aquatic ecosystems for their sustenance. The paper reviews the loss of diversification of Fish species and their current availability status in the market.
\end{abstract}

Key words: Diversity, Freshwater ecosystem, Threat.

\section{Introduction}

Ichthyodiversity refers to variety of fish species; depending on context and scale, it could refer to alleles or genotypes within piscian population. Biodiversity is also essential for stabilization of ecosystems and for protection of overall environmental quality. India is one of the megadiversity countries in the world and occupies the ninth position in terms of freshwater megabiodiversity (Mittermeir \& Mittermier, 1997). The Indian fish population represents $11.72 \%$ of species, $23.96 \%$ of genera, $57 \%$ of families and $80 \%$ of the global fishes. Out of 2200 species so far listed, 73 (3.32\%) belong to the cold freshwater regime, 544 (24.73\%) to the warm fresh waters domain, $143(6.50 \%)$ to the brackish waters and $1440(65.45 \%)$ to the marine ecosystem.

Aquaculture has been an important vector in the introduction, transfer and spread of aquatic diseases and parasites. The high risk of disease transmission and parasite infestation among species has increased the level of uncertainity which farm managers have to contend with to develop the industry. Three major reasons for the loss of diversification and loss to aquacultural practices:

- Parasite infestations

- Bacterial, Viral, Fungal and Protozoan diseases

- Introduction of Exotic species

Fishes are source of good quality protein that we can easily and completely digest. In addition, fishes are also excellent sources of polyunsaturated fatty acids. The status of health depends on the fish's genetic composition, prior history and the quality of the present environment for both, the fish and the pathogen. Environmental factors that are stressful to fish may actually provide a more optimal environment for pathogenic organisms and consequently increase their virulence. Disease can also be particularly problematic when pathogens and parasites carried by introduced species affect native species. An introduced species may find invading easier if potential predators and competitors have been decimated by disease.

The parasitic fauna, its composition, the incidence and intensity of infestations it produces, are largely determined by the host's mode of life and type of food. Thus the environmental conditions determine the general characters of the parasitic fauna and the health of host fishes.

Fish diseases due to helminth parasite are one of the important problems in fish culture and fish farming. The importance of fish parasites is related directly to the importance of the fish they may affect. Parasites can influence the health of their hosts either directly or making them less resistant to environmental stresses. Some are capable of regulating host populations and they can influence community structure through their effects on different components which can decrease market value of their fish host, while other are of public health significance. Parasites also can be used as biological tags in population studies of fish. A lot of parasites cause severe physiological disturbances and pathological conditions in the host fishes. A majority of freshwater fishes carry heavy infections of parasites which cause deterioration in the food value of fish and may even result in their mortality. Besides these, there are a number of helminth parasites which are transmitted to human beings only through fish.

Parasites are extremely abundant and diverse in nature, representing a substantial portion of global biodiversity. At least $50 \%$ of the species living on earth are parasites of some form, considering all viruses and some bacteria 
and the eukaryotic species most commonly associated with parasitology, including agents of diseases affecting not only humans, but also livestock, crops, and wildlife (Brooks \& Hoberg, 2006). Interestingly, only a small fraction of the existing species is of medical or veterinary importance (Price, 1980; Poulin \& Morand, 2004). There are many reasons to include parasites in any biodiversity survey, and indeed to study parasite diversity on its own. For example, parasites have been mentioned several times as elegant and sophisticated biological markers and as contemporary probes of biodiversity (Gardner \& Campbell, 1992). Additionally, parasite diversity provides insights into the history and biogeography of other organisms, into the structure of ecosystems, and into the processes behind the diversification of life (Brooks \& Hoberg, 2000; Poulin \& Morand, $2000,2004)$. In this context, parasites have, a dual and conflicting significance because they may regulate host populations, playing a central role in maintenance of genetic diversity and structuring host communities Brooks \& Hoberg (2006), and at the same time, they represent treats to human health, agriculture, natural systems, conservation practices, and the global economy (Horwitz \& Wilcox, 2005).

An introduced species (exotic) is any species intentionally or accidentally transported and released by man outside its present range (Kottelat and Whitten, 1996). Exotic species of fishes were introduced in many parts of the world for

- Aquarium Keeping

- Sport fishing

- Improving local fishery potential and for broadening species diversity and

- Controlling of unwanted organisms

The exotics are a competition to indigenous fishes for food and habitat. They may prey upon native fishes, introduce new diseases and parasites, resultings in the production of hybrids and cause genetic erosion of indigenous species and degradation of the physicochemical nature of aquatic ecosystems. All this will subsequently lead to loss of biodiversity (Nymann, 1991). During the last several decades over 300 species of exotic fishes have been brought into India for experimental aquaculture, sport fishing, mosquito control and aquarium keeping. A list of the important species introduced in Indian river systems are given in table. Although not many study has been carried out on the impacts of exotic fishes in Indian waters.

\section{Exotic fishes transplanted in India}

Species

A. Game Fishes

Brown trout (Salmo trutta fario)

Rainbow Trout (Salmo gairdneri)

Eastern Brook Trout (Salvelinus fontinalis)

Loch Leven Trout (Salmo levensis)

Sockeye Salmon (Oncorhyncus nerka)

Atlantic Salmon (Salmo salar)

\section{B. Food Fishes}

Golden carp (Carassius carassius)

Tench (Tinca tinca)

Gourami (Osphronemus goramy)

Common carp (Cyprinus carpio)

Tilapia (Oreochromis mossambicus)

Grass carp (Ctenopharyngodon idella)

Silver carp (Hypophthlmichthys molitrix)

Tawes (Puntius javanicus)

\section{Larvicidal fishes}

Guppy (Poecilia reticulate)

Top Minnow (Gambusia affinis)

D. Ornamental fishes

Live bearers

Egg layers

E. Unauthorised introduction

Bighead carp (Aristichthys nobilis)

African catfish (Clarias gariepinus)

Nile Tilapia (Oreochromis niloticus)

Red Tilapia (Oreochromis sp.)

Red Piranha (Serrasalmus nattereri)
Home Country

U.K.

Srilanka \&Germany

U.K.

U.K.

Japan

U.S.A

U.K.

U.K.

Java \& Mauritius

Sri lanka

Africa

Japan

Hong Kong

Indonesia

South America

Italy

From various countries

From various countries
Purpose

For planting streams, lakes \& reservoir For planting streams, lakes \& reservoir For planting streams, lakes \& reservoi For planting streams, lakes $\&$ reservoir For planting streams, lakes \& reservoir For planting streams, lakes $\&$ reservoir

Experimental culture

Experimental culture Experimental culture

Experimental culture

Experimental culture

Experimental culture

Experimental culture

Experimental culture

Mosquito control

Mosquito control

Aquarium keeping

Aquarium Keeping

Aquaculture

Aquaculture

Aquaculture

Aquaculture

Aquaculture 
Table: Environmental impact of alien fish introductions.

\begin{tabular}{|l|l|l|}
\hline Aquaculture Introduction & Environmental Impact & References \\
\hline Oreochromis mossambicus & $\begin{array}{l}\text { Displaced Gangatic carps, replaced } \\
\text { Puntius dubius and Labeo kontius } \\
\text { and now posing threat to Etroplus } \\
\text { suratensis }\end{array}$ & $\begin{array}{l}\text { Sreenivasan, 1967; Murthy } \text { et al } \\
1986 ; \text { Natrajan } \text { et al 1988; } \\
\text { Jhingran, 1991 }\end{array}$ \\
\hline Osphronemus goramy & $\begin{array}{l}\text { Naturalized but ecological implication } \\
\text { is minimal }\end{array}$ & Shetty et al 1989 \\
\hline Aristichthys nobilis & $\begin{array}{l}\text { Displacement of Catla } \text { and silver carp, } \\
\text { hybridization with silver carp }\end{array}$ & Singh and Ponniah, 2001 \\
\hline Cyprinus carpio & $\begin{array}{l}\text { Displacement of local spp. } \\
\text { Schizothorax, Osteobrama belangiri, } \\
\text { Tor putitora etc }\end{array}$ & $\begin{array}{l}\text { Shetty } \text { et al 1989; Singh \& Das } \\
2006\end{array}$ \\
\hline O. niloticus & $\begin{array}{l}\text { reduced catches of indigenous fish } \\
\text { species }\end{array}$ & $\begin{array}{l}\text { Mishra } \text { et al 2000; Sugunan, } \\
2002 ; \text { Fish Base 2004 }\end{array}$ \\
\hline Clarias gariepinus & $\begin{array}{l}\text { Environmental problem, started } \\
\text { appearing in wild posing threat to } \\
\text { biodiversity. } \\
\text { Risks of hybridization with native } \\
\text { fishes, loss to local culturable fishes }\end{array}$ & $\begin{array}{l}\text { Thakur, 1998; Barua } \text { et al 1999; } \\
\text { Mishra et al 2000; Singh and } \\
\text { Ponniah 2001 Singh and Mishra } \\
2001 \mathrm{a}, \text { b; Sugunan, 2002 }\end{array}$ \\
\hline Carassius auratus & $\begin{array}{l}\text { Hybridization with common carp in } \\
\text { nature }\end{array}$ & Shetty et al 1989; Sugunan,2002 \\
\hline Hypophthalmichthys molitrix & $\begin{array}{l}\text { Naturalized in some reservoirs and } \\
\text { displacement of Catla }\end{array}$ & $\begin{array}{l}\text { Kaushal, 1991; Pandey, 1997, } \\
\text { Singh 2004 }\end{array}$ \\
\hline Ctenopharyngodon idella & Not known & ---- \\
\hline Oncorhynchus mykiss & Unknown & ---- \\
\hline Salmo trutta fario & Eradication of local spp. & Sehgal, 1989 \\
\hline
\end{tabular}

\begin{tabular}{|c|c|c|c|}
\hline S.No & Traits of interest & Implications of aquaculture & Ecological risks \\
\hline 1 & $\begin{array}{l}\text { Tolerates harsh environment } \\
\text { including low salinity, dissolved } \\
\text { oxygen and temperature }\end{array}$ & Low management profile & $\begin{array}{l}\text { can gravitate into new } \\
\text { environments }\end{array}$ \\
\hline 3 & $\begin{array}{l}\text { Fast growth under natural as well } \\
\text { as farm conditions. }\end{array}$ & $\begin{array}{l}\text { High production attracts farmers } \\
\text { to adopt culture of this fish. }\end{array}$ & $\begin{array}{l}\text { Out-competes other local } \\
\text { species particularly C.batrachus }\end{array}$ \\
\hline 4 & $\begin{array}{l}\text { Readily accepts variety of cheap } \\
\text { feed including slaughterhouse } \\
\text { wastes. }\end{array}$ & $\begin{array}{l}\text { Aquaculture in poor quality } \\
\text { water and in derelict waters }\end{array}$ & $\begin{array}{l}\text { High chance of disease } \\
\text { outbreaks including Zonotic } \\
\text { problems. }\end{array}$ \\
\hline 5 & $\begin{array}{l}\text { Easily breeds in ponds/tanks and } \\
\text { also inundated fields. }\end{array}$ & $\begin{array}{l}\text { Auto stocking is additional } \\
\text { benefit to the farmers }\end{array}$ & $\begin{array}{l}\text { Can easily form self-sustaining } \\
\text { feral population }\end{array}$ \\
\hline
\end{tabular}

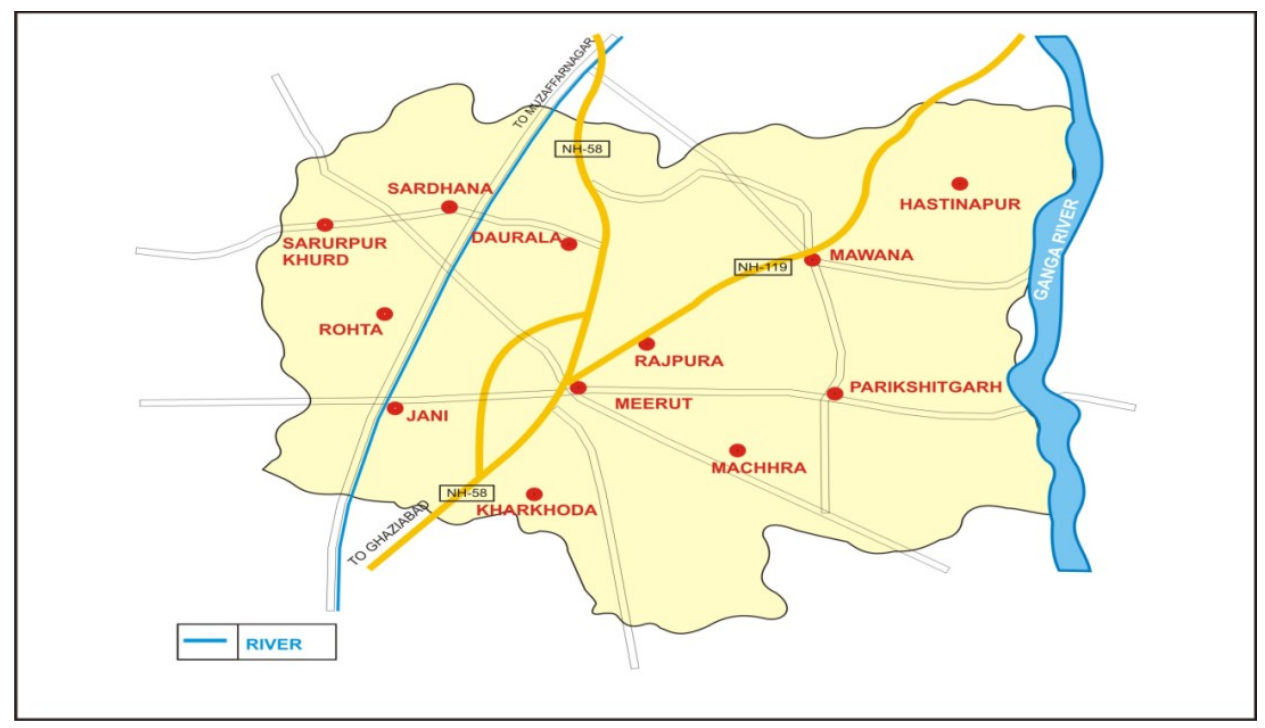

Fig: Map of Meerut showing 12 blocks which covers main fishery sources 
Fishes found in Meerut region, their family and the type of diseases reported are given in the list:

\section{FISHES}

Amblypharyngodon mola

Amphipnous cuchia

Anabas testudineus

Bagarius bagarius

Barilius bendelesis

Barilius bola

Catla catla

Chanda baculis

Channa gachua

Channa marulius

Channa punctatus

Channa striatus

Cirrhinus chaudharyi

Cirrhinus mrigala

Cirrhinus reba

Clarias hybrids

Clupisoma garua

Colisa fasciatus

Crossocheilus latius

Danio devario

Esomus danricus

Eutropiichthys vacha

Glossogobius giuris

Gudusia chapra

Hemiramphus gorakhpurensis

Heteropneustes fossilis

Hilsa tenulosa

Labeo angra

Labeo bata

Labeo boga

Labeo calbasu

Labeo dero

Labeo gonius

Labeo pangusia

Labeo rohita

Macrognathus aculeatus

Mastacembalus armatus

Mastacembalus pancalus

Mystus aor

Mystus bleekeri

Mystus cavasius

Mystus singhala

Mystus tengara

Mystus vittatus

Nandus nandus

Notopterus chitala

Notopterus notopterus

Ompok bimeculatus

Osteobrama cotio

Pangasius pangasius

Puntius conchonius

Puntius muzaffarpurensis

Puntius sarana
FAMILY

Cyprinidae

Ophiocephalidae

Anabantidae

Siluridae

Cyprinidae

Cyprinidae

Cyprinidae

Centropomidae

Ophiocephalidae

Ophiocephalidae

Ophiocephalidae

Ophiocephalidae

Cyprinidae

Cyprinidae

Cyprinidae

Clariidae

Schilbeidae

Anabantidae

Cyprinidae

Cyprinidae

Cyprinidae

Schilbeidae

Gobiidae

Clupeidae

Hemiramphidae

Saccobranchidae

Clupeidae

Cyprinidae

Cyprinidae

Cyprinidae

Cyprinidae

Cyprinidae

Cyprinidae

Cyprinidae

Cyprinidae

Mastacembelidae

Mastacembelidae

Mastacembelidae

Siluridae

Siluridae

Siluridae

Siluridae

Siluridae

Siluridae

Nandidae

Notopteridae

Notopteridae

Siluridae

Cyprinidae

Schilbeidae

Cyprinidae

Cyprinidae

Cyprinidae

\section{DISEASES}

Protozoa

Worms

Protozoa and Worms

Protozoa and Worms

Worms

Worms

Protozoa and Worms

Protozoa and Worms

Protozoa, worms, bacterial, fungal and viral

Protozoa, worms, bacterial, fungal and viral

Protozoa, worms, bacterial, fungal and viral

Protozoa, worms, bacteria, fungal and viral

DD

DD

DD

Protozoa,worms, bacterial and fungal

Protozoa and Worms

Protozoa, worms, bacterial and fungal

DD

Protozoa, Worms and Bacteria

DD

Protozoa and Worms

Protozoa and Worms

DD

DD

Protozoa, Worms and bacterial

Protozoa and Worms

Protozoa,worms, bacterial and fungal

Protozoa,worms, bacterial and fungal

Protozoa,worms, bacterial and fungal

Protozoa,worms, bacterial and fungal

Protozoa,worms, bacterial and fungal

Protozoa,worms, bacterial and fungal

Protozoa,worms, bacterial and fungal

Protozoa,worms, bacterial and fungal

Protozoa and Worms and bacterial

Protozoa and Worms and fungal

Protozoa and Worms and fungal

Protozoa and Worms and Fungal diseases

Protozoa and Worms and Fungal diseases

Protozoa and Worms and Fungal diseases

Protozoa and Worms and Fungal diseases

Protozoa and Worms and Fungal diseases

Protozoa and Worms and Fungal diseases

Protozoa and Worms and Fungal diseases

Protozoa and Worms

Protozoa and Worms

Protozoa and Worms

DD

Protozoa and Worms

Protozoa,worms, bacterial ,fungal,viral

and nutritional deficiency

Protozoa,worms, bacterial and fungal

and nutritional deficiency

Protozoa,worms, bacterial and fungal

and nutritional deficiency 
Puntius sophore

Puntius ticto

Rasbora daniconius

Wallago attu

Xenentodon cancila

DD- Data deficient

(List compiled from various published sources)

There are many fishes which were earlier found in Meerut very easily but now they are rarely seen in the market. As discussed above, reasons could be many but the problem is same i.e. the extinction of many species. A study was conducted for two years; the data was recorded and summarized in the form of table to show a list of fish species which are economically important to mankind but now hardly available in the region.

\section{RARELY AVAILABLE FISHES}

Fish

Gudusia

Hilsa tenulosa

Amblypharyngodon mola

Aspidoparia

Chagunius

Chela

Rasbora

Botia

Rita rita

Bagarius

Chaca

Ailia

Silonia

Clarias gariepinus

Aplochielus

Rhinomugil

Chanda

Badis badis
Family

Clupeidae

Clupeidae

Cyprinidae

Cyprinidae

Cyprinidae

Cyprinidae

Cyprinidae

Cobitidae

Bagridae

Sisoridae

Chacidae

Schlbeidae

Schlbeidae

Clariidae

Cyprinodontidae

Muglidae

Centropomidae

Nandidae
Protozoa,worms, bacterial and fungal and nutritional deficiency

Protozoa,worms, bacterial and fungal and nutritional deficiency

DD

Protozoa and Worms and viral diseases

Protozoa and Worms

\author{
Economic Importance \\ Food \\ Food, Commercial, Experimental \\ Food \\ Food, minor commercial \\ Food, commercial, game fish \\ Food, aquarium \\ Food, aquarium, commercial \\ Food, aquarium \\ Food, commercial \\ Food \\ Food \\ Food, commercial \\ Food, commercial, game fish \\ Food \\ Food, aquarium, commercial \\ Food, commercial, aquaculture \\ Aquarium, food \\ Food, aquarium
}

\section{Conclusion}

A large number of diseases occur in fish due to nutritional deficiency, parasitic infestation, over harvesting or unhygienic condition of water. Current trends in intensive fish farming lay emphasis on the prevention rather than treatment of fish diseases. Therapy can be applied to fish in three ways: External treatment, Systemic treatment, Parenteral treatment. India is one of the mega diversity countries with respect to freshwater species. There are plenty of culturable species and further introduction of exotic species is not required. India has to develop baseline data on the natural population potential of the indigenous species. Extreme risk areas should be indentified the effective monitoring and conservation programmes. The water bodies harboring endangered fishes must be declared as fish sanctuaries or aquatic diversity management areas.

\section{References}

[1] Mittermeier R.A, Mast R.B, Del Prado C.P and Mittermeier C.G. 1997. Megadiversity: Earth's Biologically Wealthiest Nations In R. A. Mittermeier, P. Robles Gil \& C.G. Mittermeier. (Eds.),. pp. 282-297. Monterrey, Mexico: CEMEX

[2] Brooks D. R and Hoberg E. P. 2006. Systematics and emerging infectious: From management to solution. Journal of Parasitology. 92: 426-429.

[3] Price P. W. 1980. Evolutionary Biology of Parasites. Princeton, NJ: Princeton University Press.

[4] R. Poulin and S. Morand. 2004. Parasite Biodiversity, Smithsonian Institution Books, Washington D.C., ISBN 1588341704 pp. 216

[5] Gardner S Lyell and Campbell M L. 1992., "Parasites As Probes for Biodiversity" Faculty Publications from the Harold W. Manter Laboratory of Parasitology.Paper 26.

[6] Brooks, D. R and Hoberg E. P. 2000. Triage for the biosphere: the need and rationale for taxonomic inventories and phylogenet ic studies of parasites. Comparative Parasitology 67:1-25

[7] R. Poulin and S. Morand. 2000. The Diversity of Parasites. Quart. Review of Biology 75(3):277-93.

[8] Pierre Horwitz, Bruce A. Wilcox. 2005. Parasites, ecosystems and sustainability: an ecological and complex systems perspective. International Journal for Parasitology, 35, 725-732. 
[9] Kottelat M. and Whitten T. 1996. Freshwater biodiversity in Asia with special reference to fish. World Bank Technical Paper 343, $1-59$.

[10] Nymann L. 1991. Conservation of freshwater Fish. Protection of biodiversity and genetic variability in aquatic ecosystems. Fisheries Development Series 56, Swedmar \& WWF, Sweden, 38.

[11] Singh, A.K and Lakra W.S. 2006. Alien fish species in India: Impact and emerging scenario. J. Ecophysiol. Occup. Hlth.6: 165-174. 